УДК $598.2(470.13)$

doi: $10.31140 /$ j.vestnikib.2020.1(212).3

\title{
ОСОБЕННОСТИ РАЗМНОЖЕНИЯ ПТИЦ ЗЕЛЕНЫХ НАСАЖДЕНИЙ ГОРОДА СЫКТЫВКАРА
}

\author{
С.К. Кочанов \\ Институт биологии Коми научного центра Уральского отделения Российской академии наук, Сыктывкар \\ E-mail: kochanov@ib.komisc.ru
}

\begin{abstract}
Аннотация. Изучены особенности гнездовой биологии двух видов дуплогнездников (полевого воробья - Passer montanus L. и мухоловки-пеструшки - Ficedula hypoleuca Pall.) и шести видов открытогнездящихся птиц (белой трясогузки - Motacilla alba L., дрозда-белобровика - Turdus iliacus L., дроздарябинника - Turdus pilaris L., серой вороны - Corvus cornix L., грача - C. frugilegus L. и сороки - Pica pica L.) в условиях зеленых насаждений г. Сыктывкара и его окрестностей. Показано, что в условиях культурного ландшафрта, как и в природных экосистемах, наблюдается межвидовая, сезонная и годовая изменчивость успешности размножения. Изменчивость показателей успешности размножения у разных видов зависела от совокупного действия хищничества (66-75\% общей гибели яиц и птенцов) и эмбриональной смертности (25-60 \% гибели яиц и птенцов). В городе на успешность размножения птиц большое влияние оказывает деятельность человека (25\% общей гибели яиц и птенцов), к которой, главным образом, относятся технические мероприятия, прямое разорение гнезд.
\end{abstract}

Ключевые слова: городская среда, зеленые насаждения, птицы, рост и развитие птенцов, успешность размножения

\section{Введение}

Изучение сообществ животных на городских территориях имеет большое теоретическое и практическое значение. Усиливающаяся урбанизация и сопряженное с ней возрастание техногенной нагрузки приводят к изменениям структуры сообществ животных и их основных популяционных характеристик. Изучение биологических объектов на территориях с различным уровнем антропогенного влияния важно для нормирования воздействия антропогенных нагрузок на биологические системы и выявления механизмов адаптации животных к изменяющимся условиям среды. В городском ландшафте в жизни птиц велика роль зеленых насаждений. Среди собственно городских биотопов они населены птицами наиболее плотно. Более 50 \% всех птиц, отмеченных в г. Сыктывкаре, гнездятся в парковых насаждениях (Кочанов, 2008).

Исследованию успешности размножения и роста птенцов воробьиных птиц посвящено большое количество работ (Шмальгаузен, 1935а, б, в; Лэк, 1957; Дроздов, 1967; Мина, 1976; Анорова, 1976; Познанин, 1979; Паевский, 1985; Артемьев, 1998 и др.). Установлено, что в городе успешность размножения всех дуплогнездников выше и у разных видов на 10-20\% превосходит значения контрольного показателя (Артемьев, 2005; Куранов, 2009 и др.). Скорость и продолжительность постэмбрионального роста птенцов воробьиных в условиях города находятся в прямой зависимости от размеров тела особей и длительности пребывания птенцов в гнезде. Однако успешность размножения и параметры роста и развития птенцов зависят от конкретных экологических условий и степени антропогенного воздействия на размножение птиц.

Многие стороны экологии птиц в условиях северных городов, где популяции ряда видов на- ходятся на северной границе их ареалов, изучены недостаточно. В задачи данной работы входило изучить особенности гнездовой биологии восьми модельных видов дуплогнездников и открытогнездящихся птиц в условиях зеленых насаждений г. Сыктывкара и его окрестностей.

\section{Материал и методы}

Сбор материала проведен в г. Сыктывкаре в парке им. Кирова в 1990-1991 гг. При изучении биологии размножения птиц использованы общепринятые методики. Для характеристики и анализа параметров размножения, роста и развития птенцов проанализировано 78 гнезд восьми видов птиц.

По степени увеличения массы тела и длительности пребывания птенцов в гнезде выделены два класса модельных видов:

1 класс - мухоловка-пеструшка (вес взрослой особи 10.1-15.1 г); полевой воробей (18.2-28.1 г); белая трясогузка (16.4-24.1 г).

2 класс - сорока (192-300 г); серая ворона (360-610 г); грач (350-490 г).

В основу исследования роста птенцов был положен метод изучения индивидуальных серий развития: изменение массы и линейных размеров тела одного и того же птенца прослеживали от момента вылупления до оставления им гнезда (Познанин, 1979). Взвешивание птенцов проводили на обычных висячих чашечных весах с точностью до 0.1 г. Линейные размеры тела птенцов определяли с помощью штангенциркуля с точностью до 0.1 мм.

Результаты измерений абсолютного весового показателя были дополнены вычислением удельной скорости роста птенцов в пределах двухдневного интервала. Удельную скорость роста $\left(\mathrm{C}_{\mathrm{v}}, \%\right)$ рассчитывали по формуле И.И. Шмальгаузена (1935а, б, в по: Познанин, 1979): 


$$
\mathrm{C}_{\mathrm{v}}=\frac{\lg v 2-\lg p 1}{\left(t_{2}-t_{1}\right) \times 0.4343}
$$

где $v_{1}$ и $v_{2}-$ начальная и конечная масса тела; $t_{1}$ и $t_{2}$ - возраст, соответствующий значениям массы тела.

Для оценки успешности размножения птиц учитывали число отложенных яиц, смертность птенцов, число вылетавших птенцов. По мере возможности автор старался выяснить причины гибели яиц и птенцов. Для обработки этих данных использован видоизмененный метод Мэйфилда (Mayfield, 1961), уточненный Паевским (1985). Показатели вычисляли по следующей формуле:

$$
\mathrm{q}_{\mathrm{e}}=\frac{\sum d_{e}}{\sum t_{e}} \text { и } \mathrm{q}_{\mathrm{p}}=\frac{\sum d_{p}}{\sum t n_{p}},
$$

где $\mathrm{q}_{\mathrm{e}}$ и $\mathrm{q}_{\mathrm{p}}$ - ежедневная смертность яиц и птенцов; $d_{\mathrm{e}}$ и $d_{\mathrm{p}}$ - число погибших яиц и птенцов; $n_{e}$ и $n_{p}$ - число яиц и птенцов в гнездах; $t$ - продолжительность экспозиции в днях.

\section{Результаты и обсуждение}

Урбанизация - один из крайних вариантов антропогенной трансформации природных экосистем. Для более полного анализа роста и развития птенцов в постэмбриогенезе в условиях культурного ландшафта необходимо было установить зависимость скорости и продолжительности их роста от различных факторов, как природных, так и антропогенных.

Для оценки значимости этих факторов в качестве модели нами был выбран наиболее хорошо изученный в природных условиях вид - мухоловка-пеструшка. Для достижения большей достоверности сравниваемых результатов в анализ включены данные по выводкам с одинаковым числом птенцов, так как в выводках с разным числом птенцов выявлены колебания темпов роста (табл. 1). Согласно полученным данным, на 11-15 день развития наблюдается уменьшение массы тела птенцов. Отметим, что уменьшение массы особей перед вылетом в целом характерно для воробьиных птиц (Познанин, 1979). Физиологически это связано с интенсивной дифференцировкой органов, в частности оперения, происходящей у птиц в этот период.

Выявлена зависимость скорости роста птенцов мухоловки-пеструшки от величины выводка. Мы проследили рост птенцов мухоловки-пеструшки в выводках из трех и семи птенцов (рис. 1). Установлено, что в выводке из трех птенцов они достигли максимальной массы на 11 день, в выводке из семи особей - на 14 день. При этом в данном выводке максимальная масса тела составила 14.2 г (расчетная удельная скорость роста птенцов -0.217$)$, а в выводке из семи птенцов - 13.4 г (удельная скорость роста птенцов - 0.125). Средняя величина удельной скорости роста птенцов Ficedula hypoleuca для средней России составляет 0.113 (Родимцев, 2016).

Таким образом, в условиях городского парка, как и в естественных ландшафтах (Зубцовский, 1979; Куранов, 2009) скорость роста птенцов зависит от их числа в выводке. В больших выводках птенцы растут дольше и достигают меньшей массы тела, чем в малых.

Скорость и продолжительность постэмбрионального роста птенцов воробьиных в условиях города находятся в прямой зависимости от размеров тела, характерных для вида, и длительности пребывания птенцов в гнезде.

Максимальные значения удельной скорости роста у мелких видов птиц наблюдаются в 0-1-е сутки жизни, у крупных видов - на 2-4-е сутки

Удельная скорость весового роста изученных видов птиц в постэмбриогенезе

Таблица 1

\begin{tabular}{|c|c|c|c|c|c|c|c|c|}
\hline \multirow[b]{2}{*}{$\begin{array}{c}\text { Период, } \\
\text { сутки }\end{array}$} & \multirow{2}{*}{$\begin{array}{c}\text { Дрозд- } \\
\text { белобровик }\end{array}$} & \multirow[b]{2}{*}{$\begin{array}{c}\text { Белая } \\
\text { трясогузка }\end{array}$} & \multirow{2}{*}{$\begin{array}{c}\text { Мухоловка- } \\
\text { пеструшка }\end{array}$} & \multicolumn{2}{|c|}{ Полевой воробей } & \multirow[b]{2}{*}{ Сорока } & \multirow{2}{*}{$\begin{array}{c}\text { Серая } \\
\text { ворона }\end{array}$} & \multirow[b]{2}{*}{ Грач } \\
\hline & & & & $\begin{array}{l}\text { Первая } \\
\text { кладка }\end{array}$ & $\begin{array}{l}\text { Вторая } \\
\text { кладка }\end{array}$ & & & \\
\hline $1-3$ & - & - & 47.34 & - & - & - & - & 21.75 \\
\hline $3-5$ & 13.82 & 31.96 & 25.32 & 29.14 & 13.35 & 36.84 & 32.35 & 24.26 \\
\hline $5-7$ & 8.15 & 28.78 & 20.86 & 13.77 & 12.11 & 42.59 & 26.7 & 36.73 \\
\hline $7-9$ & 2.49 & 7.27 & 10.55 & 6.4 & 4.78 & 21.41 & 33.03 & 18.53 \\
\hline $9-11$ & - & 7.71 & 5.56 & 9.7 & 0.39 & 22.59 & 9.49 & 41.56 \\
\hline $11-13$ & - & 2.30 & 3.12 & 1.29 & 0.23 & 19.0 & 5.63 & 12.66 \\
\hline $13-15$ & - & - & 0.77 & - & - & 3.22 & 11.5 & 13.35 \\
\hline $15-17$ & - & - & - & - & - & 1.96 & 5.83 & 10.36 \\
\hline $17-19$ & - & - & - & - & - & 9.09 & 4.28 & 3.11 \\
\hline $19-21$ & - & - & - & - & - & 2.42 & 0.0029 & 1.96 \\
\hline $21-23$ & - & - & - & - & - & 1.73 & 12.72 & 0.69 \\
\hline $23-25$ & - & - & - & - & - & 3.59 & 2.54 & 0.69 \\
\hline $25-27$ & - & - & - & - & - & 6.45 & 0.049 & 0.92 \\
\hline $27-29$ & - & - & - & - & - & - & 11.97 & 1.61 \\
\hline 29-31 & - & - & - & - & - & - & 10.96 & 0.35 \\
\hline $31-33$ & - & - & - & - & - & - & 4.75 & - \\
\hline
\end{tabular}
(значения скорости - для двухсуточных интервалов), \% 


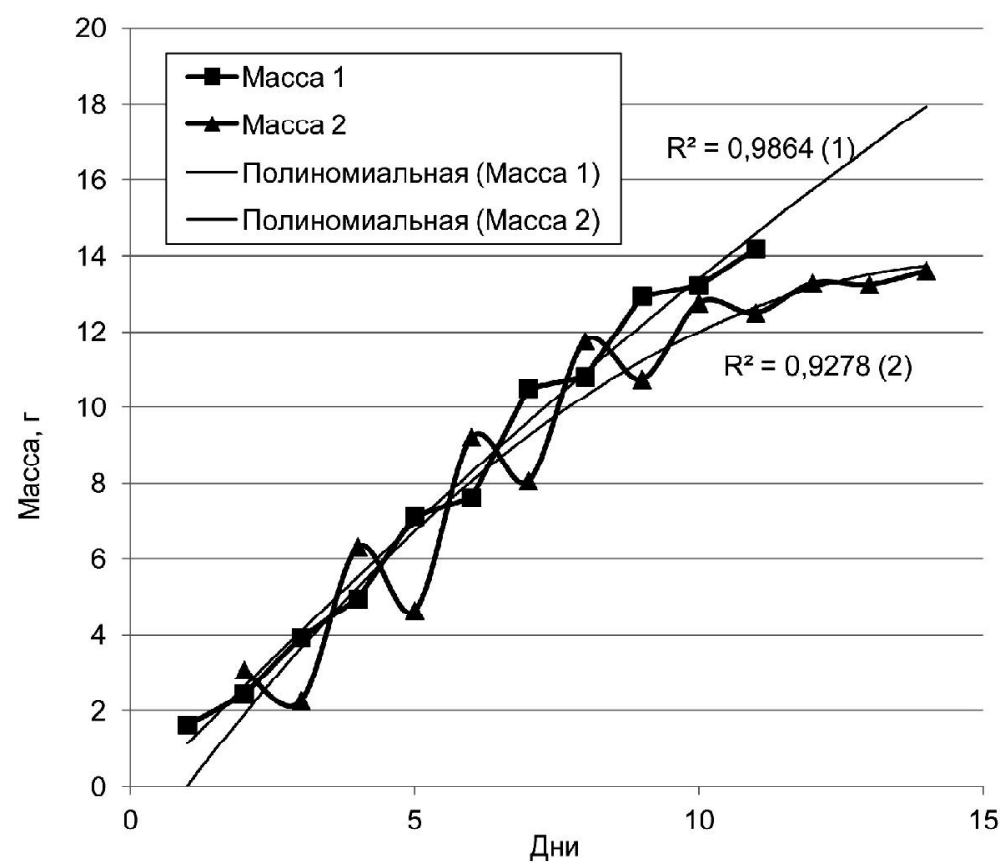

Рис. 1 Удельная скорость роста птенцов мухоловки пеструшки в маленьких (масса 1) и больших (масса 2) выводках.

(табл. 1 ; рис. 2,3 ). Они не зависят от типа гнездования, но находятся в обратной зависимости от времени нахождения птенцов в гнезде и дефинитивных размеров птиц. Это можно объяснить адаптивным значением ускоренного роста при коротком гнездовом периоде. Полученные дан-

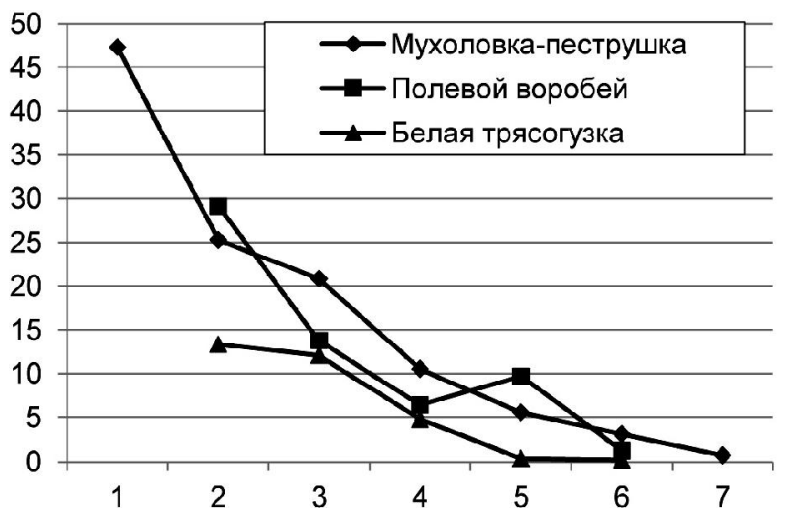

Рис. 2. Динамика удельной скорости роста птенцов мухоловки-пеструшки, полевого воробья и белой трясогузки.

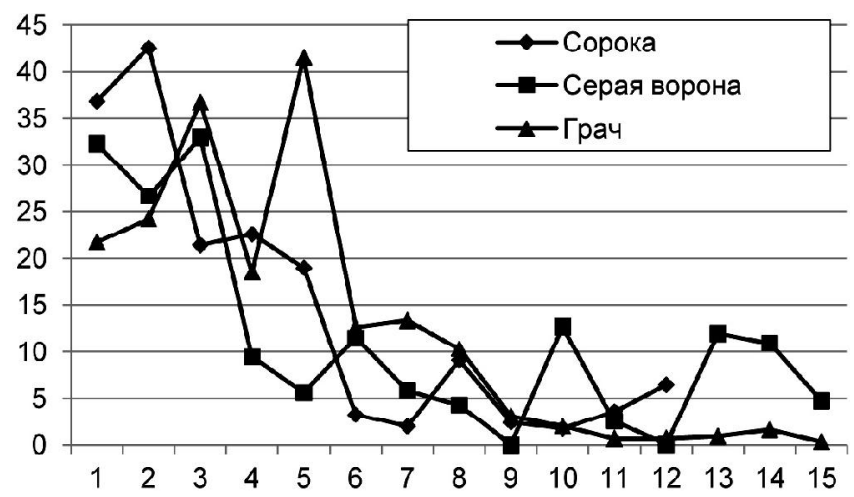

Рис. 3. Динамика удельной скорости роста птенцов сороки, серой вороны и грача. ные хорошо согласуются со сведениями, имеющимися в научной литературе (Денисова, 1971; Мина, 1976; Познанин, 1979, Родимцев, 2016).

Под успешностью размножения понимают степень выживаемости яиц и птенцов до момента вылета птенцов из гнезда. Это один из самых обычных параметров, определяемых орнитологами при стационарных исследованиях популяции. Наряду с такими показателями, как величина кладки, число выводков за сезон, скорость и продолжительность роста и развития птенцов в каждом выводке, он позволяет оценить продуктивность популяции в целом (Паевский, 1985).

В зеленых насаждениях г. Сыктывкара в 1989-1991 гг. была определена успешность размножения наиболее массовых видов птиц. Данные, приведенные в табл. 2, показывают, что среднее значение успешности размножения воробьиных в условиях городского парка равно $60.9 \%$. У открытогнездящихся видов (дрозд-рябинник, дрозд-белобровик, грач, серая ворона) величина показателя общей успешности размножения в условиях парка варьировала от 24.4 до 73.6 \% (в среднем $55 \%$ ), у закрытогнездящихся (мухоловка-пеструшка, полевой воробей, белая трясогузка) - от 61.9 до 81.8 \% (в среднем 68 \% ). В природных условиях (Ильменский заповедник) величина общей успешности размножения открытогнездящихся воробьиных птиц составляет в среднем $61.5 \%$, закрытогнездящихся - $81.6 \%$ (Зубцовский, 1979). Более низкие значения рассматриваемого показателя как у открытогнездящихся, так и у закрытогнездящихся видов воробьиных птиц в условиях парка объясняются дополнительным влиянием, которое оказывает в городе антропогенный фактор. Полученные результаты показывают, что в условиях города, как и в природных местообитаниях, успешность размножения дуплогнездников выше, чем у открытогнездящихся птиц. Этот факт, очевидно, объясняется труднодоступностью гнезд птиц первой группы и незащищенностью гнезд второй. В природе такое преимущество закрытогнездящихся видов птиц нивелируется наличием жесткой конкуренции дуплогнездников за места гнездования, которые в естественных условиях всегда в дефиците. В результате некоторым парам не удается найти подходящее место для гнезда в течение всего сезона размножения, что снижает продуктивность популяции в целом (Лэк, 1957).

Видовые различия успешности размножения воробьиных птиц на исследованной территории оказались очень большими. Необходимо подчеркнуть, что результаты получены на ограниченной территории в одном и том же сообществе птиц в 


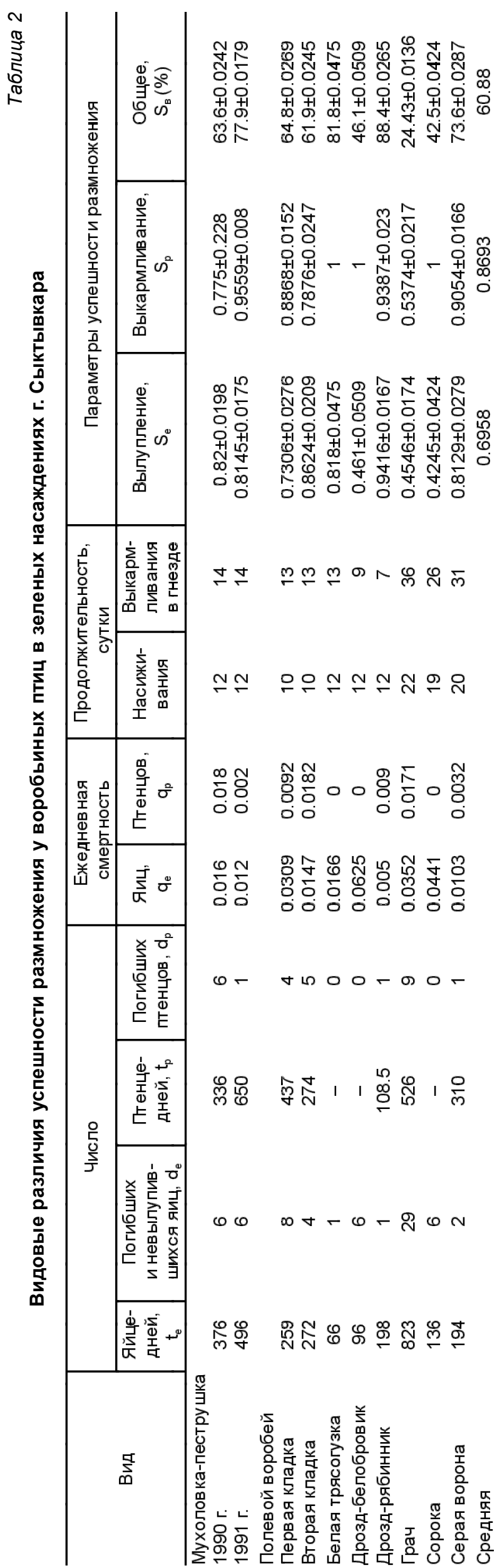

одни и те же годы. Следовательно, все наблюдаемые различия успешности размножения (от 24.4 до $88.4 \%$ ) в основном отражают различия модельных видов по признаку общей стратегии воспроизводства населения, а также по их способности противостоять отрицательным факторам окружающей среды. Максимальная успешность размножения, как показано выше, была у видов-дуплогнездников: мухоловки-пеструшки и белой трясогузки - 63.6 и $81.8 \%$ соответственно. Самая низкая успешность размножения отмечена у открытогнездящихся видов с крупными гнездами, расположенными на деревьях. У грача величина рассматриваемого показателя в парках составляла 24.4 \% хотя в целом по городу и пригородам она была несколько выше $28 \%$ (Кочанов, 2016), у сороки $-42.5 \%$. У других открытогнездящихся птиц видовые различия успешности размножения весьма значительны. У дроздабелобровика показатель составлял $46.1 \%$, серой вороны - $73.6 \%$, дрозда-рябинника $-88.4 \%$.

Установлено, что на успешность размножения птиц оказывают влияние как многие внешние (хищничество, ресурсы пищи, погода, сроки размножения, гнездовой паразитизм), так и внутрипопуляционные (плотность популяции, возраст партнеров, постоянство брачных пар, эмбриональная смертность) факторы.

В городском ландшафте человек предоставляет птицам дополнительные ресурсы пищи, места для гнездования, что способствует увеличению плотности популяции в целом, устраняет гнездовой паразитизм и т.п. Необходимо определить, какие из факторов, влияющих на успешность размножения птиц, наиболее значимы в городе.

Хищничество, т.е. поедание яиц и птенцов, является частным случаем разорения гнезд. Нами установлено, что роль хищников в условиях зеленых насаждений города играют врановые, дятлы (особенно для дуплогнездников), а также кошки и собаки. По расчетам деятельность этих хищников в районе исследований привела к гибели 44 \% от числа всех погибших яиц и $61 \%$ - птенцов. При этом удельный вес гибели яиц и птенцов зависел от двух основных причин: степени защищенности гнезда и интенсивности его защиты. Отмечено, что у закрытогнездящихся видов - дуплогнездников (воробей полевой, мухоловка-пеструшка, белая трясогузка) от хищничества гибнут в основном птенцы (65\% общей смертности птенцов), а у открытогнездящихся (грач) - яйца (75\% общей смертности яиц).

Межвидовые различия успешности размножения таких сходных по биологии гнездования видов, как дрозд-рябинник (88.4\%) и дрозд-белобровик $(46.1 \%)$, грач $(24.4 \%)$ и серая ворона (73.6\%), объясняются разной стратегией воспроизводства населения (интенсивность защиты гнезда). Если для дроздарябинника и серой вороны характерна высокая агрессивность при защите гнезда, то дрозд-белобровик при нападении хищников предпочитает отводить их от гнезда, а не прогонять, активно нападая. 
У грачей яйца в кладках пропадали в достаточно большом количестве (в кладке из трех-пяти яиц обычно оставалось по одному-два), хотя особи данного вида отличаются достаточной агрессивностью в отношении хищников. Объяснением этого факта, возможно, является каннибализм в колониях грачей. В успешности гнездования дроздов, несомненно, существенную роль играет и высота крепления гнезда: дрозд-белобровик строит свои гнезда на гораздо меньшей высоте (до 34 м), чем дрозд-рябинник (до 10-12 м).

Таким образом, хищничество, как один из внешних факторов, влияющих на успешность размножения вида птиц, тесно связан с внутрипопуляционным фактором - гнездовым поведением вида пернатых.

У видов-дуплогнездников в связи с использованием «механической» защиты гнезда агрессивное поведение не играет столь важной роли в биологии размножения, как у открытогнездящихся птиц. Пассивная защита гнезда (механическое укрытие и скрытная деятельность родителей) эффективна при насиживании яиц (ежедневная смертность яиц 0.01-0.03 против 0.03-0.06 у открытогнездящихся видов), но теряет значение при вылуплении птенцов. После вылупления потомства у видов-дуплогнездников в связи с увеличением активности родителей у гнезда и самих птенцов происходит увеличение ежедневной смертности птенцов с 0.009 до 0.02 против 0.003-0.009 у открытогнездящихся видов.

В связи с малым отходом яиц у видов-дуплогнездников по причине хищничества важное значение в эффективности размножения приобретает эмбриональная смертность. У модельных видов эмбриональная смертность составила в среднем $63 \%$ от общей гибели яиц. Наибольшая эмбриональная смертность (77 \%) отмечена у закрытогнездящихся видов (мухоловка-пеструшка и полевой воробей), наименьшая (25\%) - у открытогнездящихся птиц (грач, серая ворона). Полученные нами данные согласуются с имеющимися в литературе (Зубцовский, 1979; Паевский, 1985; Куранов, 2009).

Важным фактором, определяющим особенности размножения птиц, являются и погодные условия. Зависимость сроков миграции, стадий гнездового цикла и успешности размножения птиц от погодных условий достаточно полно освещена в литературе (Лэк, 1957; Шилов, 1968; Щеблыкина, 1985). Предполагается, что наиболее значимыми для успешности размножения погодными факторами являются температура и осадки, которые в свою очередь определяют состав кормовой базы и готовность стаций для гнездования (Лэк, 1957; Щеблыкина, 1985).

В 1990 г. весна (май) характеризовалась аномально холодной погодой со средней температурой $5.2{ }^{\circ} \mathrm{C}$ (на $2-5{ }^{\circ} \mathrm{C}$ ниже нормы), частыми осад- ками в виде мокрого снега и дождя. Первая декада июня также была холодной $\left(10{ }^{\circ} \mathrm{C}\right)$, незначительное потепление (до $15{ }^{\circ} \mathrm{C}$ ) наблюдали только к середине июня. В результате этого начало строительства гнезд у мухоловки-пеструшки происходило в третьей декаде мая, а откладка яиц в первых числах июня. Сроки откладки яиц были максимально сжаты (менее одной недели).

Май 1991 г. отличался очень теплой погодой со средней температурой $13{ }^{\circ} \mathrm{C}$, что превышает норму на $5-10{ }^{\circ} \mathrm{C}$. В связи с этим гнездостроение мухоловки-пеструшки началось раньше - во второй декаде мая, а откладка яиц происходила в третьей декаде этого месяца, когда средняя температура достигла $19.5{ }^{\circ} \mathrm{C}$ (на $11{ }^{\circ} \mathrm{C}$ выше температуры соответствующей декады 1990 г.). Сроки откладки яиц по сравнению с 1990 г. были растянуты и занимали период от последней декады мая до первой декады июня.

В южных районах Республики Коми в естественных условиях мухоловка-пеструшка обычно приступает к откладке яиц в конце первой начале второй декады июня. В период наших исследований начало откладки яиц происходило раньше - в третьей декаде мая (1991 г.) и первой декаде июня (1990 г.). Сдвиг сроков начала откладки яиц на более ранние даты в условиях города, возможно, связан с тем, что температура воздуха в городской черте на $2-3{ }^{\circ} \mathrm{C}$ выше, чем за городом (Зимин, 1988). Ход погодных явлений отразился на показателе успешности выкармливания птенцов мухоловки-пеструшки, значение которого в 1991 г. составило $95.5 \%$, в 1990 г. $77.5 \%$. Общая успешность размножения мухоловки в 1990 г. была $63.6 \%$, в 1991 г. - $77.9 \%$. Исходя из этих данных, можно констатировать, что погодные условия определяют параметры успешности размножения. Наибольший успех выкармливания птенцов насекомоядных птиц и, следовательно, максимальная величина общей успешности размножения отмечены при сочетании наибольших температур и минимального количества выпавших осадков.

Существуют и сезонные различия этого показателя. Наиболее часто они проявляются в меньшей выживаемости птенцов, вылупившихся в конце сезона, по сравнению с особями, появившимися на свет в начале сезона. Это относится и к позднее начатым первым кладкам, и ко вторым кладкам. Ранее это явление было отмечено для воробьиных и чаек (Паевский, 1985). Различия можно объяснить сезонными изменениями обилия предпочитаемой пищи и/или уровнем пресса хищников, который меняется в течение лета.

Наиболее удобным объектом для изучения сезонной динамики выживаемости птенцов в городе является полевой воробей. В условиях городского парка особи данного вида делают две клад- 
ки за сезон. В результате исследований, проведенных в 1990 г., мы определили, что успешность размножения первой кладки полевого воробья составила $64.8 \%$, второй на $2.8 \%$ ниже $61.9 \%$. Аналогичные явления наблюдали и для мухоловки-пеструшки. В 1990 г. смещение сроков откладки яиц на более позднее время в совокупности с другими факторами способствовало худшей успешности размножения (63.6 \%) в сравнении с 1991 г. (77.9\%).

Таким образом, в условиях зеленых насаждений города, так же как и в природных популяциях (Зубцовский, 1979), наблюдается сезонная изменчивость успешности размножения птиц, которая наряду с межвидовой и годовой изменчивостью определяется совокупным действием хищничества, погодных условий, эмбриональной смертности. При этом не следует забывать и о «факторе беспокойства», который как составная часть хозяйственной деятельности, безусловно, влияет на успешность размножения гнездящихся в городской черте птиц.

В городском парке в 1990 г. не было отмечено ни одного случая гибели гнезда по причине «фактора беспокойства». В 1991 г. зарегистрировано одно брошенное гнездо дрозда-белобровика, построенное на небольшой высоте (2 м) рядом с дорожкой. Столь незначительное действие этого фактора в условиях парка можно объяснить тем, что ядро населения птиц в парках составляют экологически и этологически пластичные виды, находящиеся на различных стадиях адаптации $\kappa$ антропогенному воздействию и, соответственно, более толерантные к беспокойству со стороны людей. Эти виды различными способами приспособились избегать «фактора беспокойства». Так, в парке дрозды располагают гнезда на высоте до 10-15 м, в природе - на высоте 3-4 м. Дрозды-рябинники активно защищают свои гнезда.

Большое влияние на успешность гнездования птиц в зеленых насаждениях городов могут оказать различные технические мероприятия, проводимые человеком. Например, скашивание газонов в парках совпадает по времени с вылетом молодых дроздов-рябинников. В результате слетки лишаются естественного укрытия - густой травы, становясь легкой добычей собак и кошек. В связи с этим расчетное значение успешности размножения дрозда-рябинника к моменту вылета птенцов из гнезда $(88.4 \%)$ не отражает реальную ситуацию, так как после вылета гибнет еще 50-60 \% молодых птиц. Следовательно, у дроздов-рябинников основная смертность приходится не на стадии насиживания и выкармливания птенцов в гнезде, а на период после вылета слетков из гнезда.

\section{Заключение}

На основе данных, полученных при исследованиях в зеленых насаждениях г. Сыктывкара, выявлено, что показатели роста и развития птенцов в постэмбриональный период в условиях города в целом сходны с таковыми в природных условиях. Продолжительность и скорость роста птенцов возрастают при увеличении размеров тела, характерных для данного вида птиц, и длительности периода размножения. Интенсивность роста птенцов открытогнездящихся видов птиц выше, чем у закрытогнездящихся. Птенцы в больших выводках растут медленнее, их максимальные размеры меньше, чем у птенцов в маленьких выводках. Темпы роста и развития птенцов зависят от погодных условий - снижение среднесуточной температуры воздуха способствует задержке развития птенцов. Отличия для популяций птиц природных и городских ландшафтов выражаются лишь в незначительном увеличении продолжительности периода набора птенцами максимального веса в городской черте, что может являться следствием «фактора беспокойства».

Результаты исследований успешности размножения воробьиных птиц в зеленых насаждениях города показали, что в условиях городского ландшафта проявляется межвидовая, сезонная и годовая изменчивость успешности размножения. Изменчивость показателей успешности размножения у разных видов определяется хищничеством (66-75\% общей гибели яиц и птенцов) и эмбриональной смертностью (25-60\% гибели яиц и птенцов). В условиях города на успешность размножения птиц большое влияние оказывает раннее скашивание травы, прямое разорение гнезд (25\% общей гибели яиц и птенцов).

Аналитическая работа и подготовка рукописи статьи выполнены в рамках государственного задания отдела экологии животных Института биологии Коми НЦ УрО РАН (АААA-А17-117112850235-2).

\section{ЛИТЕРАТУРА}

Анорова, Н. С. Размножение популяции мухоловки-пеструшки в зависимости от возраста птиц / Н. С. Анорова // Орнитология. - 1976. - Вып. 12. - С. 7786.

Артемьев, А. В. Демография мухоловки-пеструшки в Приладожье. Характеристика репродуктивного цикла / А. В. Артемьев // Фауна и экология наземных позвоночных Республики Карелия. - Петрозаводск : КарНЦ РАН, 1998. - С. 32-57.

Артемьев, А. В. Периферические популяции политипического вида в северной зоне ареала (на примере мухоловки-пеструшки Ficedula hepoleuca) : автореф. дис. ... докт. биол. наук / А. В. Артемьев. - Петрозаводск, 2005. - 52 с.

Денисова, М. Н. Особенности роста воробьиных птиц в Заполярье в связи с расселением видов / М. Н. Денисова, 3. В. Артамонова // Зоологический журнал. - 1971. - Т. 50, № 5. - С. 741-750. 
Дроздов, Н. Н. Фауна и население птиц культурного ландшафта / Н. Н. Дроздов // Орнитология. 1967. - Вып. 8. - С. 3-46.

Зимин, В. Б. Экология воробьиных птиц СевероЗапада СССР / В. Б. Зимин. - Ленинград : Наука, 1988. - 184 с.

Зубцовский, Н. Е. Эффективность размножения воробьиных птиц в Ильменском заповеднике / Н. Е. Зубцовский // Структурно-функциональные взаимосвязи в биогеоценозах Южного Урала : сборник статей. - Свердловск, 1979. - С. 106-109.

Кочанов, С. К. Разнообразие и структура летнего населения зеленых насаждений городов Республики Коми / С. К. Кочанов // Разнообразие и пространственно-экологическая организация животного населения европейского Северо-Востока. - Сыктывкар, 2008.С. 161-173. - (Труды Коми НЦ УрО РАН ; № 184).

Кочанов, С. К. Экология грача (Corvus frugilegus Linnaeus, 1758) на северной границе его распространения (европейский северо-восток России) / С. К. Кочанов, Е. В. Данилова // Вестник Института биологии Коми НЦ УрО РАН. - 2016. - № 2 (196). - С. 12-17.

Куранов, Б. Д. Гнездовая биология урбанизированной популяции мухоловки-пеструшки (Ficedula hypoleuca) / Б. Д. Куранов // Вестник Томского государственного университета. - 2009. - № 297. - С. 192200.

Лэк, Д. Численность животных и ее регуляция в природе / Д. Лэк. - Москва, 1957. - 187 с.

Мина, М. В. Рост животных / М. В. Мина, Г. А. Клевезаль. - Москва : Наука. - 1976. - 292 с.

Паевский, В. А. Демография птиц / В. А. Паевский. - Ленинград : Наука, 1985. - 285 с.
Познанин, Л. П. Эколого-морфологический анализ онтогенеза птенцовых птиц (общий рост и развитие пропорций тела в постэмбриогенезе) / Л. П. Познанин. - Москва : Наука, 1979. - 296 с.

Родимцев, А. С. Особенности роста массы тела полуптенцовых и птенцовых птиц в гнездовой период / А. С. Родимцев, А. И. Ермолаев // Зоологический журнал. - 2016. - Т. 95, № 7. - С. 837-847.

Шилов, И. А. Экологические аспекты проблемы эволюции гомойотермии / И. А. Шилов // Зоологический журнал. - 1968. - Т. 47, № 9. - С. 1285-1295.

Шмальгаузен, И. И. Определение основных понятий и методика исследования роста / И. И. Шмальгаузен // Рост животных. - Москва, 1935а. - С. 8-60.

Шмальгаузен, И. И. Рост и дифференцировка / И. И. Шмальгаузен // Рост животных. - Москва, 1935б. - С. 74-84.

Шмальгаузен, И. И. Рост и общие размеры тела в связи с их биологическим значением / И. И. Шмальгаузен // Рост животных. - Москва, 1935в. - С. 6173.

Щеблыкина, Л. С. Влияние погодных факторов на сроки прилета, гнездования и успешность размножения некоторых дендрофильных воробьиных птиц / Л. С. Щеблыкина // Фауна и экология наземных позвоночных животных на территории с разной степенью антропогенного воздействия : Межвузовский сборник научных трудов. - Москва : МГПИ, 1985. - С. 130143.

Mayfield, H. Nesting success cleculated from exposure / H. Mayfield // Wilson Bull. - 1961. - Vol. 2, N 1. - P. 169-178.

\title{
BIRDS BREEDING IN THE PLANTINGS OF SYKTYVKAR
}

\author{
S.K. Kochanov \\ Institute of Biology of Komi Scientific Centre of the Ural Branch of the Russian Academy of Sciences, Syktyvkar
}

Summary. Here we studied the features of nesting biology of two cavity nesting bird species (field sparrow Passer montanus L. and pied flycatcher Ficedula hypoleuca Pall.) and six species of open-nesting birds (white wagtail Motacilla alba L., red-winged thrush Turdus iliacus L., fieldfare Turdus pilaris L., gray crow Corvus cornix L., rook Corvus frugilegus L., and magpies Pica pica L.) in the plantings of Syktyvkar and its vicinities. We found that the growth and development indicators of nestlings in the post-embryonic period in the city are generally similar to those in natural conditions. The duration and growth rate of the nestlings increase with increasing size of the body and the length of breeding period. The growth rate of nestlings of open-nesting birds is higher than that of closed-nesting species. Nestlings in large clutches grow slowly and are smaller those in small clutches. The growth and development rates of nestlings depend on weather conditions: a decrease in the average daily temperature contributes to a delay in the development of nestlings. The differences are expressed only in a minimal increase of the period of gaining the maximum weight of the nestlings, which may be a consequence of the «disturbance factor». The data on the success of breeding passerines showed that interspecific, seasonal, and annual variability of breeding success is characteristic both in the urban and natural landscapes. The variability of reproduction success rates of different species is determined by predation (66-75\% of the total death of eggs and nestlings) and embryonic mortality (25-60\% of the death of eggs and nestlings). Under the urban conditions, the success of bird breeding is greatly influenced by the «disturbance factor», technical measures, and the direct ruin of nests (25\% of the total death of eggs and nestlings).

Key words: city plantings birds, breeding biology, breeding success 